\title{
Performance of Front line Demonstration on Yield Enhancement of Mustard in Barmer District of Rajasthan
}

\author{
Pradeep Pagaria*, L. R. Choudhary, Hari Dayal, Ganga Ram and Turfan Khan
}

Krishi Vigyan Kendra, Barmer II (Raj.), India

*Corresponding author

\section{A B S T R A C T}

Keywords

Mustard, Oilseed, Productivity, Front line Demonstration etc

Article Info

Accepted:

04 November 2019

Available Online:

10 December 2019
Krishi Vigyan Kendra conducted front line demonstration on Mustard variety PM-26 and Giriraj at farmers' fields in district Barmer during years 2015-16 to 2018-19. The productivity and economic returns of Mustard in demonstrated plots were calculated and compared with the corresponding local check. The data obtained was pooled for four years. It was observed that on an average 32.18 percent higher grain yield was recorded in demonstration plots than the local check. The extension gap, technology gap and technology index were $3.90 \mathrm{q} / \mathrm{ha}, 3.27 \mathrm{q} / \mathrm{ha}$ and 16.32 percent, respectively. An additional investment of Rs. ha coupled with scientific monitoring of demonstration and non-monetary factors resulted in additional return of Rs. 16576/ha over the farmers practices. Fluctuating minimum selling price of Mustard during different years influenced the economic returns per unit area.

\section{Introduction}

Krishi Vigyan Kendra an innovative science based institution plays an important role in bringing the research scientist face to face with farmers. The main aim of Krishi Vigyan Kendra is to reduce the time lag between generations of technology at the research institution and its transfer to the farmers for increasing productivity and income from the agriculture and allied sectors on sustained basis. KVKs are grass root level organizations meant for application of technology through assessment, refinement and demonstration of proven produce technologies under different micro farming situations in a district (Das, 2007). Front line demonstration is a long term educational activity conducted in a systematic manner at farmers' fields to prove the worth of a new practice/technology. Farmers in India are still producing crops based on the knowledge transmitted to them by their forefathers leading to a grossly unscientific agronomic, nutrient management and pest 
management practices. As a result of these, they often fail to achieve the desired potential yield of various crops and new varieties. Barmer district is in Western zone the traditional cropping systems of this district is Bajra/Pulse-Cumin/Isabgol. The soil is low in organic carbon, medium in $\mathrm{P}$ and $\mathrm{K}$. till date the productivity level of Mustard is not sufficient on account of several causes like unavailability of quality seeds of improved varieties in time and poor crop management practices due to unawareness and non adoption of recommended production and plant protection technologies. Therefore, it is very essential to demonstrate the high yielding varieties, resistant to biotic and abiotic stresses and other production technologies which the framers generally do not adopt. Keeping above points in view Front line demonstration was conducted on Mustard by Krishi Vigyan Kendra. The main objectives of the study were to exhibit the performance of recommended high yielding Mustard varities with recommended practices for harvesting higher crop yields. To compare the yield levels of local check (farmers practices) and FLD plots. To collect feedback for further improvement in the performance of Mustard cultivation practices.

\section{Materials and Methods}

The front line demonstrations on Mustard were conducted at farmer's field in district Barmer to assess its performance during the year 2015-16 to 2018-19. The soil of the district is generally sandy to sandy loam in texture which is low organic carbon (0.2 - 0.3 $\%$ ), available phosphorus (14-17 kg/ha) and medium to high in potash. Each demonstration was of 0.4 ha area and the critical inputs were applied as per the package of practices. The quality seed of Mustard variety during all the years of the study was used for conducting FLD. The sowing was done during October and harvested during March (Table 1).
Demonstrated at farmers fields were regularly monitored by scientist of Krishi Vigyan Kendra from sowing to harvesting. The grain yield of demonstration crop was recorded and analyzed. Different parameters were calculated to find out technology gaps (Yadav et al., 2004) as follows:

Extension gap $=$ Demonstration yield - Local check yield

Technology gap $=$ potential yield Demonstration yield

Technology index $=$ Potential yield Demonstration yield x 100/Potential Yield

\section{Results and Discussion}

\section{Grain yield}

On an average the demonstrated plots showed 32.18 per cent increase in grain yield (Table $2)$. The highest increase in grain yield (46.15 $\%)$ was observed in year 2018-19 it which might be due to seed of improved and other improved variety technologies about which the farmers were ignorant.

\section{Extension gap}

An extension gap between demonstrated technology and farmers practices range from 5.7 to $3.2 \mathrm{q} /$ ha during different four years and on average basis the extension gap was 3.90 $\mathrm{q} /$ ha (Table 2). This gap might be attributed to adoption of improved technology in demonstrations which resulted in higher grain yield than the traditional farmer's practices.

\section{Technology gap}

Wide technology gap were observed during different years and this was lowest (0.3 q/ha) during 2015-16 and was highest during (7.17 $\mathrm{q} /$ ha) during 2017-18. The average technology 
gap returns found was $3.27 \mathrm{q} / \mathrm{ha}$. The difference in technology gap during different years could be due to more feasibility of recommended technologies during different years. Similarly, the technology index for all the demonstrated during different years were in accordance with technology gap. Higher technology for transferring to farmers and insufficient extension services for transfer of technology.

\section{Technology index (\%)}

On an average the demonstrated plots showed 16.32 per cent increase in technology index (Table 2). The highest increase in technology index $(37.84 \%)$ was observed in year 2017-18 it which might be due to seed of improved and other improved variety technologies about which the farmers were ignorant.

\section{Economic gap}

Different variables like seed, fertilizers, bio fertilizers and pesticides were considered as critical inputs for the demonstration as well as farmers practices and on an average an additional investment of Rs. 2396/ha were made under demonstrations. The highest incremental benefit: cost ratio was 2.67 during the year 2015-16. Overall average BCR was found to be 2.38. The results confirm the findings of frontline demonstrations on oilseed and pulses crops by Yadav et al., (2004) and Lathwal (2010).

Frontline demonstration programme was effective in changing attitude of farmers towards Mustard cultivation. Cultivation of demonstrated plots of Mustard with improved technologies has increased the skill and knowledge of the farmers. FLD also helped in replacement of local non recommended varieties with improved recommended varieties. This also improved the relationship between farmers and scientist and built confidence between them. The farmers where improved technology was demonstrated also acted as primary source of information for other farmers on the improved practices of Mustard cultivation and also acted as source of good quality pure seeds in their locality for the next crop. The concept of Front line demonstration may be applied to all farmer categories including progressive farmers for speedy and wider dissemination of the recommended practices to other members of the farming community.

Table.1 Particulars showing the details of mustard grown under front line demonstrations and farmers practices

\begin{tabular}{|c|c|c|c|}
\hline S. No. & Particulars & $\begin{array}{c}\text { Farmers practice (Local } \\
\text { Check) }\end{array}$ & Frontline demonstration \\
\hline 1 & Variety & Local var. & PM-26/Giriraj \\
\hline 2 & Seed rate $(\mathrm{kg} / \mathrm{ha})$ & 4-5 & 2.5 \\
\hline 3 & Seed treatment & No & $\begin{array}{c}\text { Metalaxyl 35 SD @6.0 gm/kg } \\
\text { Seed }\end{array}$ \\
\hline 4 & $\begin{array}{c}\text { Azatobacter and P.S.B } \\
\text { culture }\end{array}$ & No treatment & $\begin{array}{l}\text { Seed treatment with Azatobacter } \\
\text { and P.S.B culture }\end{array}$ \\
\hline 5 & Line spacing & $22.5 \mathrm{~cm}$ & $30 \mathrm{~cm}$ \\
\hline 6 & Sowing time & Mid Oct. -Nov. & 15 Oct. -30 oct. \\
\hline 7 & Nutrient Management & $32: 23: 0$ & $60: 30: 0$ \\
\hline 8 & Pest management & $\begin{array}{l}\text { No use of plant protection } \\
\text { measures }\end{array}$ & $\begin{array}{c}\text { Foliar spray of Imidacloprid@ } \\
0.33 \text { ml/liter of water At } \\
\text { flowering stage }\end{array}$ \\
\hline
\end{tabular}


Table.2 Grain yield and gap analysis of frontline demonstration on mustard at farmer's field

\begin{tabular}{|c|c|c|c|c|c|c|c|c|c|}
\hline \multirow[t]{2}{*}{ Year } & \multirow[b]{2}{*}{ Var. } & \multirow{2}{*}{$\begin{array}{l}\text { No. of } \\
\text { Demo. }\end{array}$} & \multirow{2}{*}{$\begin{array}{l}\text { Area } \\
\text { (ha) }\end{array}$} & \multicolumn{2}{|c|}{ Yield (q/ha) } & \multirow{2}{*}{$\begin{array}{c}\text { Increase } \\
(\%)\end{array}$} & \multirow{2}{*}{$\begin{array}{l}\text { Extension } \\
\text { gap (q/ha) }\end{array}$} & \multirow{2}{*}{$\begin{array}{l}\text { Technology } \\
\text { gap (q/ha) }\end{array}$} & \multirow{2}{*}{$\begin{array}{l}\text { Technology } \\
\text { index }(\%)\end{array}$} \\
\hline & & & & Demon. & $\begin{array}{l}\text { Local } \\
\text { check }\end{array}$ & & & & \\
\hline 2015-16 & PM26 & 20 & 10 & 18.65 & 15.2 & 22.70 & 3.45 & 0.3 & 1.58 \\
\hline 2016-17 & PM26 & 20 & 25 & 17.8 & 14.6 & 21.92 & 3.2 & 1.15 & 6.07 \\
\hline 2017-18 & PM26 & 25 & 10 & 11.78 & 8.54 & 37.94 & 3.24 & 7.17 & 37.84 \\
\hline 2018-19 & Giriraj & 38 & 30 & 18.05 & 12.35 & 46.15 & 5.7 & 4.45 & 19.78 \\
\hline Average & & 25.75 & 18.75 & 16.57 & 12.67 & 32.18 & 3.90 & 3.27 & 16.32 \\
\hline
\end{tabular}

Table.3 Economic analysis of demonstrated plots and farmers practice

\begin{tabular}{|c|c|c|c|c|c|c|c|c|c|c|c|}
\hline \multirow[t]{2}{*}{ Crop } & \multirow[t]{2}{*}{$\begin{array}{c}\text { Themati } \\
\text { c area }\end{array}$} & \multirow[t]{2}{*}{ Variety } & \multirow{2}{*}{$\begin{array}{c}\text { Demo } \\
\text { area } \\
\text { (ha) }\end{array}$} & \multirow[t]{2}{*}{$\begin{array}{c}\text { Farmers } \\
\text { (No.) }\end{array}$} & \multicolumn{3}{|c|}{ Yield (q/ha) } & \multicolumn{2}{|c|}{$\begin{array}{c}\text { Net returns } \\
\text { (Rs./ha) }\end{array}$} & \multicolumn{2}{|c|}{ BCR } \\
\hline & & & & & Demo & Check & Increase (\%) & Demo & Check & Demo & Check \\
\hline 2015-16 & Mustard & PM26 & 20 & 10 & 18.65 & 15.20 & 22.70 & 64000 & 40000 & 2.67 & 1.67 \\
\hline 2016-17 & Mustard & PM26 & 20 & 25 & 17.80 & 14.60 & 21.92 & 66045 & 52500 & 2.54 & 2.04 \\
\hline 2017-18 & Mustard & PM26 & 25 & 10 & 11.78 & 8.54 & 37.94 & 38874 & 17140 & 1.79 & 1.37 \\
\hline 2018-19 & Mustard & Giriraj & 38 & 30 & 18.05 & 12.35 & 46.15 & 75810 & 46034 & 2.55 & 2.03 \\
\hline
\end{tabular}

References

Khan, P. M. and Chouhan, J. (2005). Demonstration - An effective technology for increasing the productivity of gram. Indian Res. J. Ext. Edu., 16: 221-223.

Lathwal OP (2010). Evaluation of frontline demonstration on blackgram in irrigated agro ecosystem. Annals of Agricultral Research 31 (1\&2) 24-27.

Singh, P.K., Barman, K.K. and Varshney, J.G. (2011). Adoption behaviour of vegetable growers towards improved technologies. Indian Res. J.Ext. Edu. 11(1): 62-65.

Singh, P. K. and Varshney, jay G. (2010). Adoption level and constraints in coriander production technology. Indian Res. J. Extn. Edu., 10 (1): 91-94.

Yadav D B, Kamboj B K and garg R B (2004). Increasing the productivity and profitability of sunflower through frontline demonstration in irrigated agroecosystem of eastern Haryana. Haryana J. of Agronomy 20 (1\&2): 3335. i

Vital Agriculture Statistics (2010-11): Directorate of Agriculture, Rajasthan, Jaipur.

Veersamy, S., satpathy, c. and Rao, G. A. (2003). Constraints of coriander production in Orissa. Indian Res. $J$. Extn. Edu., 33 (1\&2): 58-63.

\section{How to cite this article:}

Pradeep Pagaria, L. R. Choudhary, Hari Dayal, Ganga Ram and Turfan Khan. 2019. Performance of Front line Demonstration on Yield Enhancement of Mustard in Barmer District of Rajasthan. Int.J.Curr.Microbiol.App.Sci. 8(12): 425-428. doi: https://doi.org/10.20546/ijcmas.2019.812.056 